\title{
Serum CEA Measurement
}

National Cancer Institute

\section{Source}

National Cancer Institute. Serum CEA Measurement. NCI Thesaurus. Code C157252.

The determination of the amount of carcinoembryonic antigen present in a serum sample. 